\title{
Regeneration ability in seventeen top soil and sub soil earthworm species
}

Authors Info

D. Banik and P. S. Chaudhuri*

Department of Zoology,

Earthworm Research Laboratory, Tripura University,

Suryamaninagar-799 022, India

*Corresponding Author Email : priya_1956@rediffmail.com

\section{Key words}

Eudrilus eugeniae, Lampito mauritii,

Perionyx excavatus,

Polypheretima elongata,

Regeneration ability

Publication Info

Paper received : 14.12 .2015

Revised received: 14.03 .2016

Re-revised received : 18.08 .2016

Accepted: 12.09 .2016
ISSN: 0254-8704 (Print) ISSN: 2394-0379 (Online) CODEN: JEBIDP
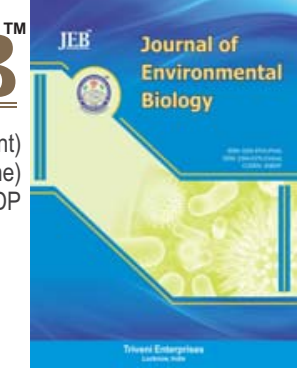

Abstract

Aim: The present study was carried out to record the regeneration ability in the top soil earthworm species inhabiting $0-15 \mathrm{~cm}$ soils with unpredictable environment and exposed to predator pressure and the sub soil species living below $15 \mathrm{~cm}$ soil depth where environment was stable with less exposure to predators.

Methodology: Out of a total of 17 laboratory acclimatized earthworm species, 12 top soil and 5 sub soil species were subjected to amputation of either anterior (5) or posterior (5) body segments or both by sterilized blade. Amputed earthworms in separate experimental groups were kept in decomposed cow dung (epigeic species) and habitat soils (for others) under laboratory conditions (temperature $26^{\circ} \mathrm{C} \pm$ $0.22, \mathrm{RH} 70-90 \%$ ).

Results: In contrast to the sub soil earthworm species, the top soil species in generaly had the ability of regeneration of body segments. Top soil species viz., Perionyx excavatus, Eisenia fetida, Eudrilus eugeniae, Octochaetona beatrix, Lampito mauritii, Glyphidrilus sp., Dichogaster sp., Drawida papillifer papillifer, Drawida assamensis, Pontoscolex corethrurus and Polypheretima elongata had the regeneration ability and of them only former seven species restored both anterior and posterior amputed segments, while rest of the species regenerated only the posterior segments.

Interpretation: In contrast to the sub soil earthworm species viz., Eutyphoeus gammiei, E. comillahnus, Metaphire houlleti, Amynthus alexandri and Kanchuria sp., the top soil species in general were subjected to predator

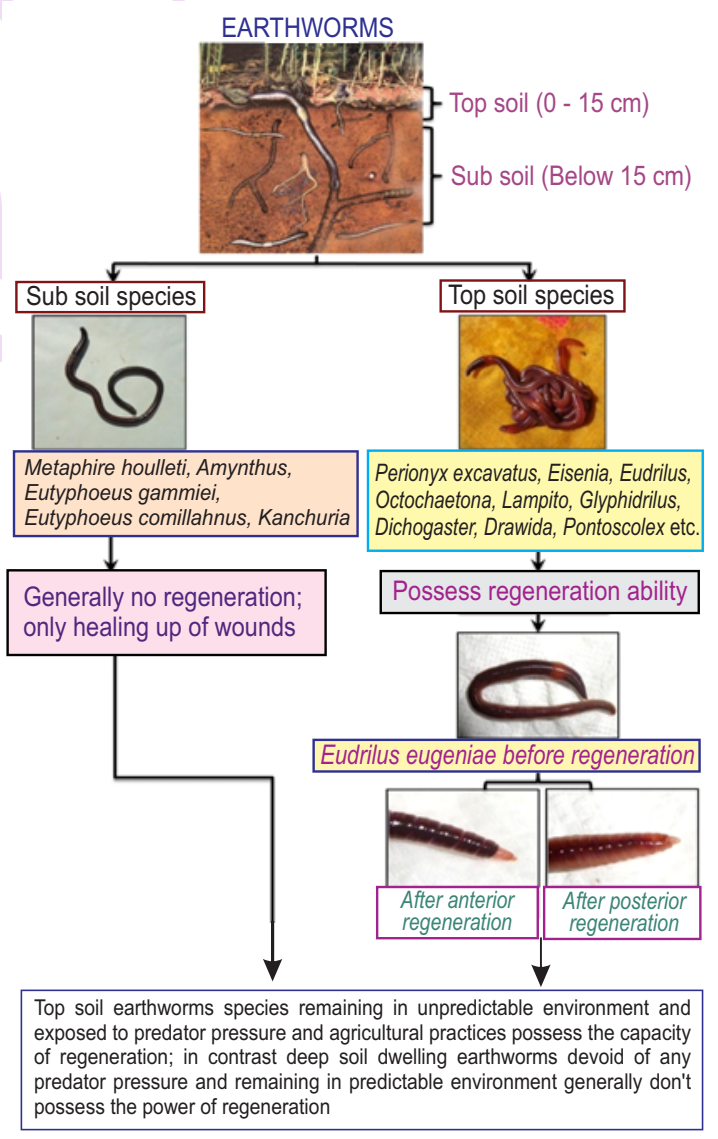
attacks and agricultural practices (ploughing) leading to loss of segments, and thus were equipped with the power of regeneration. 


\section{Introduction}

The capacity of regeneration in animals is less marked. It is well known that sponges, hydras and planarians can regenerate whole organisms from small body segments (morpholactic regeneration). Earthworms (Annelida: Oligochaeta) which are morphologically more complex than hydras and planarians, exhibit variable degree of regeneration (Edwards and Bohlen, 1996). Although in recent years most of the research work on earthworms are concentrated on vermicomposting (Edwards, 2011; Biradar and Biradar, 2015; Chaudhuri et al., 2016) and biodiversity (Chaudhuri and Nath, 2011; Lalthanzara et al., 2011; Chakraborty and Chaudhuri 2016; Jamatia and Chaudhuri, 2017) less attention has been paid on their regeneration biology (Nanda and Chaudhury, 1982).

Bouche (1971) recognized three major ecological groups of earthworms: epigeic, anecic and endogeic. Epigeic earthworms (similar to Lee's litter species) are typically deeply pigmented, living on the litter above the soil surface. Dorsally pigmented anecic earthworms (Lee's top soil species) form permanent or semi permanent vertical burrows in soils and feed on soils with decaying leaves. Endogeic earthworm species (Lee's subsoil species) are generally nonpigmented or less pigmented, inhabit the mineral soil horizon and typically geophagous in nature. In tropical ecosystems, endogeic are divided into three subcategories, polyhumic, mesohumic and oligohumic depending upon the amount of organic matter taken (Edwards and Bohlen, 1996). Moreover, some tropical earthworm species under anecic category shares some characters of epigeic, hence are called epianecic species. These three major ecological groups are evolutionary extremes on three corners of a triangle with many species occupying intermediary positions with respect to these extremes (Edwards and Bohlen, 1996).

In fact, regeneration ability is one of the important factors that affect the survival of earthworms in their ecology. According to Edwards and Bohlen (1996) capacity of regeneration of injured or lost part of the bodies of earthworms varies and ranges from a very poor capacity for regrowth in Lumbricus terrestris to species that seem to be able to regenerate almost any organ, such as those belonging to genera Criodrilus and Perionyx (Edwards and Bohlen, 1996). Deep burrowing earthworm, Eutyphoeus gammiei (endemic to north- east India) lacks the ability of either anterior or posterior regeneration (Chaudhuri et al.,1998). Survival rates of earthworms in response to amputation treatments depend on the number of segments remaining and are much related to the position of amputation (Xiao et al., 2011).Anterior regeneration lengths are correlated with the position of amputation, but not with the number of remaining segments. The posterior regeneration lengths, however, are not correlated with number of remaining segments, nor the position of amputation (Xiao et al., 2011).

In the present study, regeneration ability of 17 earthworm species belonging to different ecological categories was studied. As earthworm species inhabiting different vertical distribution in soils were exposed to variable degree of agricultural practices (ploughing) or predator attacks leading to loss of body segments, it can be predicted that the earthworm species exposed mostly to such factors do possess better regenerative power.

\section{Materials and Methods}

Seventeen earthworm species belonging to three major ecological categories viz. Epigeic (Perionyx excavatus, Eisenia fetida, Eudrilus eugeniae), Endogeic (Glyphidrilus sp.,Octochaetona beatrix, Dichogastersp., Drawida assamensis, Pontoscolex corethrurus, Metaphire posthuma, Lampito mauritii, Polypheretima elongata, Eutyphoeus commillahnus, Eutyphoeus gammiei, Kenchuria sp.) and Anecic (Metaphire houlleti, Amynthus alexandri, Drawida papiliffer papillifer) were selected for regeneration studies during June to October of 2014-2015. Epigeic species like $P$. excavatus, E. fetida and E. eugeniae were collected from laboratory stock cultures, while rest of the species were collected from Agartala (W. Tripura) and its neighbouring areas. In the present study earthworm species inhabiting $0-15 \mathrm{~cm}$ soil depth were considered as top- soil species, while those inhabiting more than $15 \mathrm{~cm}$ soil depth were sub- soil species. Thus, A. alexandri, M. houlleti, E. commillahnus, E. gammiei and Kanchuria sp. living in deep soil were sub-soil species, while the rests twelve species were top-soil earthworms. Species collected from their natural habitats were acclimated for one week under laboratory conditions (temperature $26{ }^{\circ} \mathrm{C} \pm 0.22, \mathrm{RH} 70-90 \%$ ) prior to regeneration studies.

Five treatment groups (Group I - Group V) were considered for regeneration experiment. Each group had 10 adult individuals of a species which were washed in distilled water before treatment .In group I, individuals were selected for studies on anterior regeneration where anterior most five segments were amputed at inter segmental groove $5 / 6$ by using sterilized scalpel. In group II, individuals were selected for posterior regeneration where the last five caudal segments were amputed. The group I and group II individuals were kept on moisturized filter paper in sterilized Petri-dishes covered with lids, taking care of proper aeration. Following healing up of wounds after $24-72 \mathrm{hrs}$, the amputed earthworms (group I and group II) were released separately into earthen pots with suitable feed substrates (partly decomposed cow dung for $P$. excavatus, E. fetida, E. eugeniae, habitat soils for other species). Although regeneration was completed within 18 (for anterior regeneration) to 28 days (for posterior regeneration), the experiment was continued for 60 days for restoration of normal pigmentation and original size of lost body segments.

Based on the ability of regeneration other three treatment groups were used. In group III, earthworm species with anterior regeneration ability viz. P. excavatus, E. fetida, E. eugeniae, 0 . beatrix and $L$. mauritii, anterior amputation was made following $10^{\text {th }}$ segment (10/11 segment). In group IV (P. excavatus, $E$. 
eugeniae, E. fetida), simultaneous transection of five body segments from both the anterior and posterior most body parts of the same individual were made. Specimens ( $P$. excavatus) belonging to Group $V$ were cut medially into two equal halves. Group III- V were maintained similar to group I and group II. Regenerated segments were counted under magnifying glass. All amputation treatments were replicated three times.

\section{Results and Discussion}

Following amputation of either anterior or posterior segments different species of earthworms displayed interesting behavioral changes. While M. posthuma had lost its characteristic knot forming behavior (following disturbance), earthworm species like $P$. corethrurus, $D$. papillifer papillifer and Dichogaster $\mathrm{sp}$. formed a tight knot (simulating 'diapause' condition) after amputation. M. houlleti and $A$. alexandri did not display their characteristic serpentine movement following amputation. Coelomic fluid was forcefully ejected out by $E$. gammiei, $E$. comillahnus and Kenchuria sp. after amputation. Species like $E$. eugeniae, E. fetida, D. assamensis and Glyphidrilus sp. showed wave of muscular contraction along their body axis often leading to autotomy, following amputation of body segments. Regeneration of different earthworm species is shown in Fig. 1.

Wound healing took place in most of the species within 15 days. Among the species studied, epigeic species, P. excavatus formed regeneration blastema at the earliest i.e. $24 \mathrm{hrs}$ after amputation. Surface dwelling litter species ( $P$. excavatus, $E$ fetida, E. eugeniae) and top soil endogeic species viz. Dichogaster sp., Glyphidrilus sp., O. beatrix, L. mauritii had the ability of both anterior and posterior regeneration (Table1). In $P$. excavatus, $E$. eugeniae and $E$. fetida, while 12-14 days were required for restoration of five segments after anterior amputation, same number of segments regenerated following posterior amputation of 16-17 days indicating anterior regeneration a much faster process than posterior regeneration. Time required for restoration of segments during anterior and posterior regeneration in different earthworm species is given in Table 1. Among other top-soil dwellers, $D$. papillifer papillifer, $D$. assamensis, $P$. corethrurus and $P$. elongata had the ability of posterior regeneration only (Table 1). Six earthworm species viz., E. gammiei, E. comillahnus, Kenchuria sp., M. posthuma, M houlleti and $A$. alexandri did not show any sign of either anterior or posterior regeneration. The anteriorly amputed species, lacking regeneration ability (e.g. E. gammiei) died after few days but survived following posterior transection with healing of wounds. Among 17 species studied 11 species viz., P. excavatus, E. fetida, E. eugeniae, O. beatrix, L. mauritii, Glyphidrilus sp., Dichogaster sp., $D$. papillifer papillifer, $D$. assamensis, $P$. corethrurus and $P$. elongata had the ability of posterior regeneration, and the former seven species, among them were able to regenerate both anterior and posterior body segments (Table 1).

Epigeic species like P. excavatus, E. fetida, E. eugeniae and top soil endogeic species like $O$. beatrix, L. mauritii under group III treatment, restored all the segments following amputation of anterior 10 segments (Table 2). In this treated group, epigeic species not only took less time for restoration of lost anterior segments as compared to the top soil endogeic species (O. beatrix, L. mauritii) (Table 2), their mortality rate was also less $(20 \%)$ than the latter $(50 \%)$.

Epigeic earthworms, P. excavatus, E. fetida, E. eugeniae under group IV treatment, regenerated all the anterior and posterior segments with $30-40 \%$ mortality following simultaneous transection of five anterior and five posterior most body segments (Table 3). Simultaneous regeneration of anterior and posterior body segments following segment loss indicates that in the epigeic species regeneration is bidirectional (Cho et al., 2009).

P. excavatus had tremendous potential of regeneration of lost body parts. Thus, Perionyx under Group V treatment, when cut into two halves produced two viable individuals with original anterior part regenerating more than 25-29 posterior segments and the posterior part restoring 18 anterior segments including clitellum, digestive, nervous and reproductive systems (Fig. 2).

The present study revealed that Annelidsphylogenetically the first group of coelomates, with well developed central nervous system, a closed vascular system and metameric segmentation exhibit extensive variations in regeneration ability (Bely, 2010). In fact, earthworms may be regarded as the best metazoan models to study different aspects of regeneration because they are relatively easy to culture and manipulate in the laboratory. Therefore, oligochaetes would be more suitable than Hydras or planarians as experimental material to enhance the regeneration ability in vertebrates (Xiao et al., 2011).

Epigeic and top-soil endogeic earthworm species in general, show the capacities of regeneration, in contrast to those species dwelling in the sub- soils. Epigeic and top- soil endogeic earthworms are often subjected to predator attacks and their bodies are cut into pieces by soil cultivators during ploughing. So nature has gifted them the power of regeneration. In contrast, deep soil dwelling earthworms devoid of any predator pressure and remaining in predictable environment generally do not possess the power of regeneration. Absence of regeneration ability in $M$. houlleti and $A$. alexandri, in spite of, being top soil inhabitants may be linked to their rapid serpentine movement (following disturbance) that help them to escape from the predator attacks (Chaudhuri, 2006). Similarly, M. posthuma lacking regeneration ability coils around the body following disturbance of any kind of touch sensation (Chaudhuri, 2006).

Regeneration in earthworms is epimorphic i.e. by addition of parts to the remaining piece of the body, in contrast to the morpholloactic type (remodeling the available mass of cells into a new individual) as in hydras (Balinsky, 1981). In earthworms, 

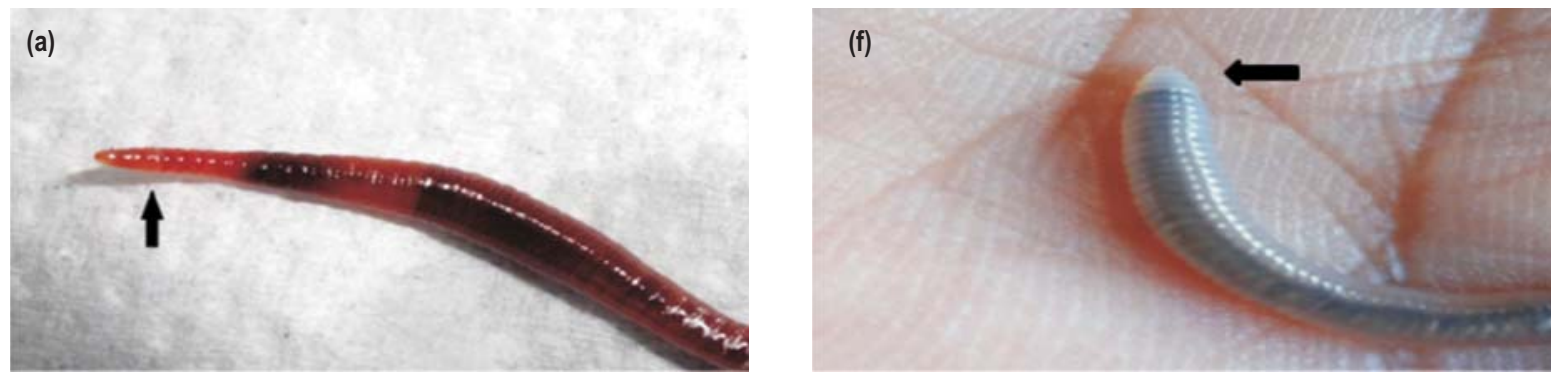

(b)

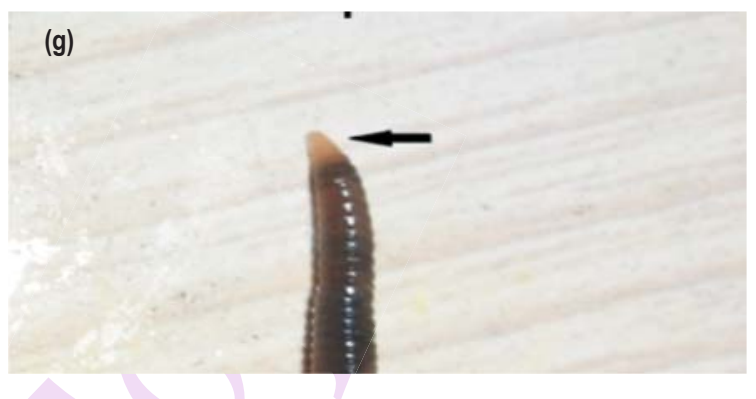

(c)
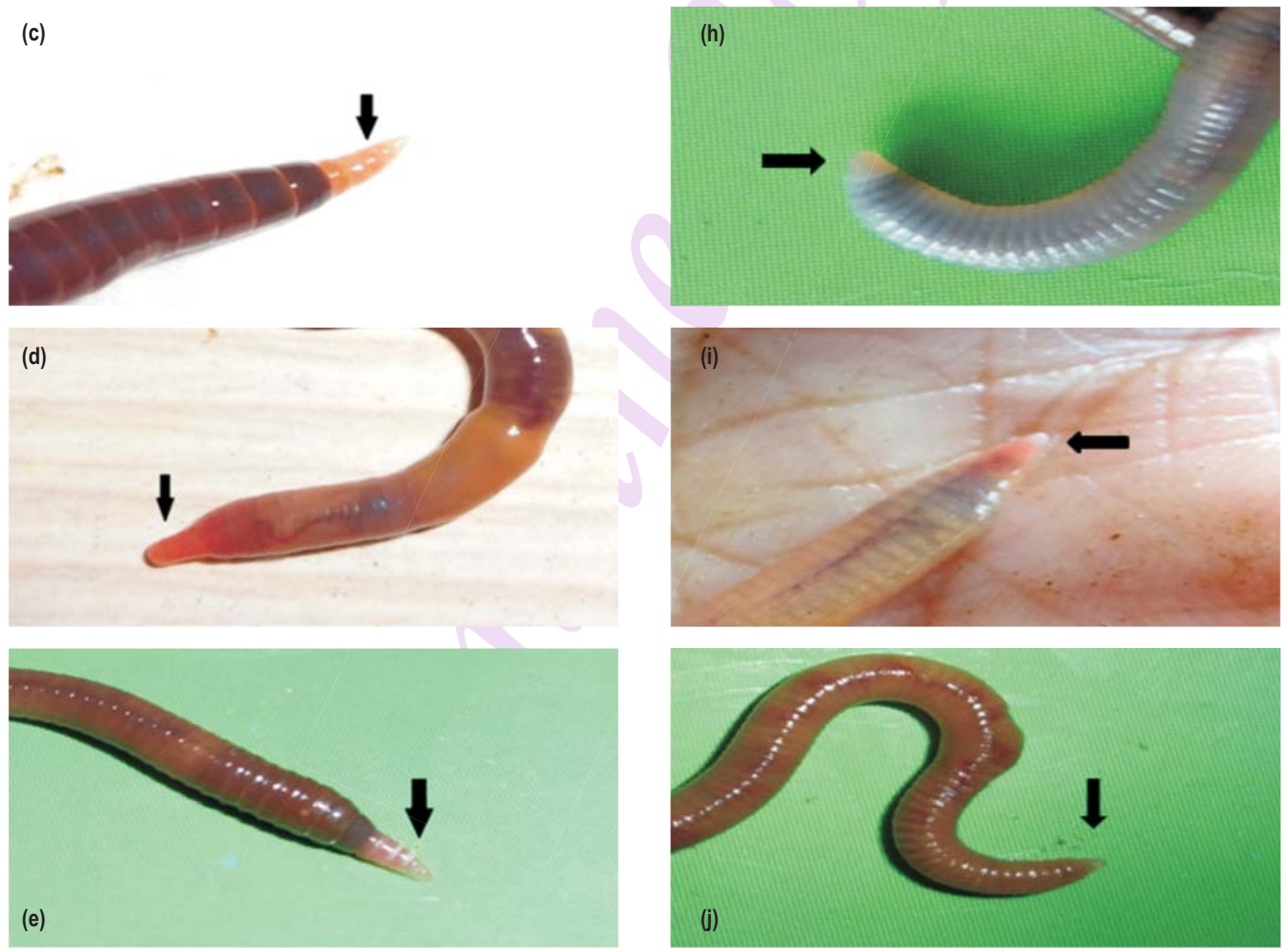

Fig. 1 : Regeneration in earthworms: anterior regeneration in (a) Perionyx excavatus; (b) Eudrilus eugeniae; (c) Eisenia fetida; (d) Lampito mauritii; (e) Octochaetona beatrix and posterior regeneration in (f) Octochaetona beatrix; (g) Lampito mauritii; (h) Pontoscolex corethrurus; (i) Drawida assamensis; (j) Drawida papillifer papillifer 


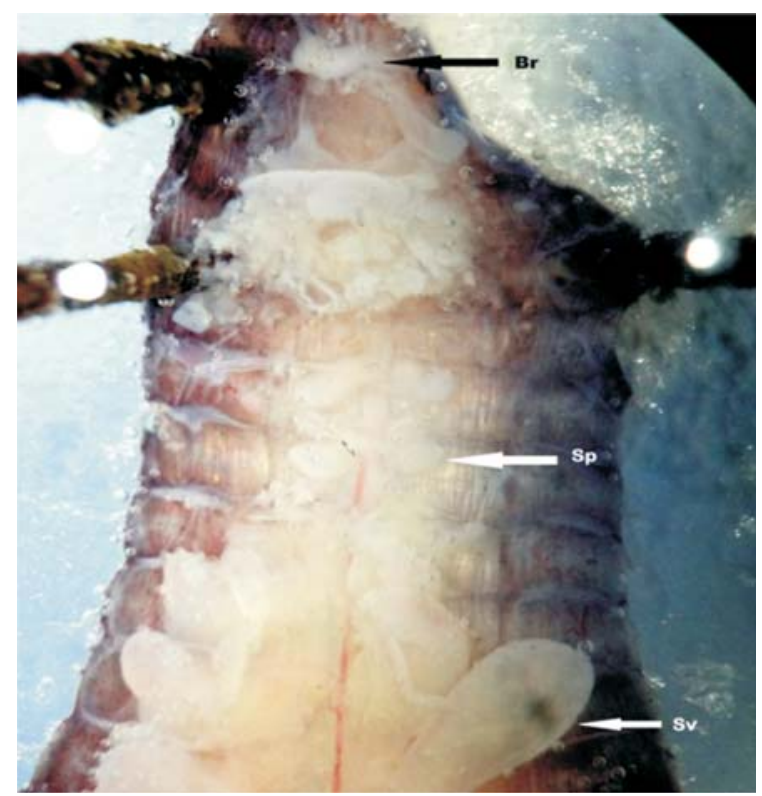

Fig. 2 : Regeneration of nerve ring and reproductive organs in $P$. excavatus bisected medially. Br-brain, SV-seminal vesicle, SPspermatheca

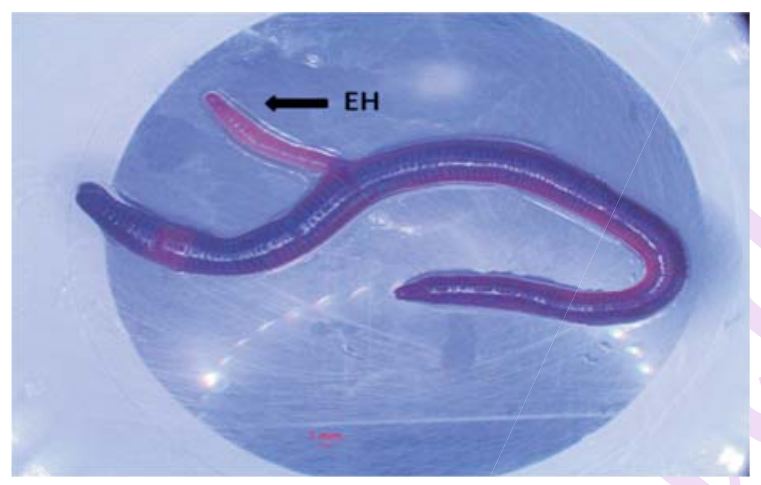

Fig. 3 : Regenerated 'extra head ' (EH) in P. excavatus

regeneration begins with blastema formation at the amputation end, followed by cellular proliferation and differentiation into head or tail bud (Xiao et al., 2011). Although incident of posterior regeneration in earthworms is much more than anterior regeneration (Edward and Bohlen, 1996), the latter process in much quicker than the former. Appearance of nerve ring with regeneration of the neurosecretory system in Metaphire peguana following 10 days of anterior amputation was reported earlier by Nanda and Chaudhuri (1983). The reason behind anterior regeneration being a quicker process than the posterior regeneration is probably due to the fact that formation of mouth for feeding and circumoesophageal nerve ring with its neurosecretory elements for its role in segment proliferation, are essential factors for regenerative growth in earthworms. Literature is available on the role of neurohormone released by neurosecretory cells of central nervous system in the process of regeneration in earthworms (Nanda and Chaudhury, 1982; Banik and Chaudhuri, 2016; Okrzesik et al., 2013).

The study revealed that earthworm species with the power of anterior regeneration also has the ability to regenerate lost posterior segments (e.g. Perionyx, Eisenia, Eudrilus, Lampito and Dichogaster etc.). But those with the capacity of posterior regeneration may not have the ability to restore the lost anterior segments following amputation (e.g. P. elongata, P. corethrurus, $D$. assamensis, D. papillifer papillifer). Tremendous potential of Indian vermicomposting earthworm, $P$. excavatus to regenerate complete sets of different organ systems including central nervous system and reproductive organs were quite interesting. Recently, Cho et al. (2009) reported reformation of various tissues and organs of blood vascular system, central nervous system, excretory system, following amputation in $P$. excavatus. In the recent study a regenerated 'extra head' posterior to the clitellum of adult Perionyx excavatus (Fig. 3) in its culture bed under laboratory conditions was recorded. Regeneration of this 'extra head' was probably due to post- clitellar injury during specimen handling in culture bed. Thus, the present study indicates that the earthworm is the highest evolutionary form capable of regenerating an anterior portion with all the vital systems of the body.

The study showed that regeneration occurred more readily when the 'tail' was cut off rather than the 'head'. The full number of segments was not always regenerated. The number of regrown segments depends on the length of the remaining fragments of the body (Xiao et al., 2011). There is a gradual decrease in regeneration capacity along the body from front to back (Edwards and Bohlen, 1996). According to Tweeten and Anderson (2008) head regeneration in fresh water oligochaetes $L$. variegates involves dedifferentiation, proliferation and redifferentiation of cells at the wound site while regeneration of tails is dependent on migration of cells to the cut site. The chloragogen cells are important in earthworm regeneration, because there is a mass migration of these cells to the wound after part of the worm is cut off (Edwards and Bohlen, 1996). However, a 'critical inhibitor voltage theory' suggested that the formation of new segments continues at the tip of the earthworms until a critical inhibitory voltage is builtup (Edwards and Bohlen, 1996).

Neurohormone released from the neurosecretory cells at the central nervous system plays an important role in regeneration, particularly in initiating regeneration in Eisenia fetida, Metaphire peguana, Eudrilus eugeniae (Moment, 1979; Nanda and Chaudhuri, 1982; Banik and Chaudhuri, 2016). In epigeic earthworms (homodynamic species), which are more prone to predatory attacks and do not enter diapauses, may readily regenerate lost segments by altering the levels of neurohormone released by ventral nerve cord and cerebral 
Table 1: Regeneration ability in seventeen species of earthworms $(n=20),(d=45),\left(R T=27^{\circ} \mathrm{C} \pm 0.2^{\circ} \mathrm{C}\right)$

\begin{tabular}{|c|c|c|c|c|c|c|c|c|}
\hline \multirow[t]{2}{*}{ Species } & \multicolumn{4}{|c|}{ Anterior regeneration } & \multicolumn{4}{|c|}{ Posterior regeneration } \\
\hline & $\begin{array}{l}\text { No. of } \\
\text { anterior } \\
\text { segments } \\
\text { amputed }\end{array}$ & $\begin{array}{l}\text { Regener- } \\
\text { ation ability }\end{array}$ & $\begin{array}{l}\text { No. of } \\
\text { segments } \\
\text { regenerated }\end{array}$ & $\begin{array}{l}\text { No. of days for } \\
\text { regeneration }\end{array}$ & $\begin{array}{l}\text { No. of } \\
\text { posterior } \\
\text { segments } \\
\text { amputed }\end{array}$ & $\begin{array}{l}\text { Regener- } \\
\text { ation } \\
\text { ability }\end{array}$ & $\begin{array}{l}\text { No. of } \\
\text { segments } \\
\text { regenerated }\end{array}$ & $\begin{array}{l}\text { No. of days for } \\
\text { regeneration }\end{array}$ \\
\hline \multicolumn{9}{|l|}{ Top soil species } \\
\hline P. excavatus & 5 & + & 5 & $12.1 \pm 0.2$ & 5 & + & 5 & $16.15 \pm 0.19$ \\
\hline E. fetida & 5 & + & 5 & $14.1 \pm 0.31$ & 5 & + & 5 & $17.75 \pm 0.25$ \\
\hline E. eugeniae & 5 & + & 5 & $12.6 \pm 0.27$ & 5 & + & 5 & $17.45 \pm 0.13$ \\
\hline O. beatrix & 5 & + & 5 & $14.85 \pm 0.26$ & 5 & + & 5 & $26.95 \pm 0.33$ \\
\hline L. mauritii & 5 & + & 5 & $18.9 \pm 0.32$ & 5 & + & 5 & $17.80 \pm 0.36$ \\
\hline Glyphidrilus sp. & 5 & + & 5 & $13.4 \pm 0.31$ & 5 & + & ID & ID \\
\hline Dichogastersp. & 5 & + & 5 & $9.6 \pm 0.28$ & 5 & + & $4.45 \pm 0.21$ & $12.75 \pm 0.03$ \\
\hline D. papilliferpapillifer & 5 & - & 0 & - & 5 & + & $4.30 \pm 0.19$ & $23.6 \pm 0.21$ \\
\hline D. assamensis & 5 & - & 0 & - & 5 & + & $5 \pm 0.21$ & $27.75 \pm 0.3$ \\
\hline P. corethrurus & 5 & _- & 0 & - & 5 & + & $3.5 \pm 0.2$ & $20.25 \pm 0.49$ \\
\hline M. posthuma & 5 & - & 0 & - & 5 & - & 0 & - \\
\hline P. elongata & 5 & _- & 0 & - & 5 & + & $3 \pm 0.15$ & $17.7 \pm 0.22$ \\
\hline \multicolumn{9}{|l|}{ Sub soil species } \\
\hline M. houlleti & 5 & - & 0 & - & 5 & - & 0 & - \\
\hline Amynthus alexandri & 5 & - & 0 & _- & 5 & _- & 0 & _- \\
\hline E. commilahnus & 5 & - & 0 & - & 5 & - & 0 & - \\
\hline E. gammiei & 5 & - & 0 & - & 5 & - & 0 & - \\
\hline Kenchuriasp. & 5 & - & 0 & - & 5 & - & 0 & - \\
\hline
\end{tabular}

$n=$ number of individuals, $d=$ total day of observation, $R T=$ room temperature, $I D$ - ill defined; Values are $\pm S E$

Table 2: Comparison in power of anterior regeneration among top- soil earthworm species

\begin{tabular}{llll}
\hline Species & Anterior segments amputed & Segments regenerated & Days to restore lost segments (Mean \pm SE) \\
\hline Perionyx excavatus & 10 & 10 & $13.75 \pm 0.21$ \\
Eudrilus eugeniae & 10 & 10 & $16.35 \pm 0.34$ \\
Eisenia fetida & 10 & 10 & $21.9 \pm 0.46$ \\
Octochaetona beatrix & 10 & 10 & $20.9 \pm 0.22$ \\
Lampito mauritii & 10 & 10 & $23.5 \pm 0.35$ \\
\hline
\end{tabular}

Values are $\pm S E$

Table 3 : Segment restoration in epigeic earthworms following simultaneous anterior and posterior transaction (Group IV)

\begin{tabular}{lllll}
\hline Species & $\begin{array}{l}\text { Anterior and posterior } \\
\text { simultaneous amputation }\end{array}$ & $\begin{array}{l}\text { Total anterior and } \\
\text { posterior segments } \\
\text { emerged }\end{array}$ & $\begin{array}{l}\text { Days required to regenerate } \\
\text { anterior segments }\end{array}$ & $\begin{array}{l}\text { Days required to regenerate } \\
\text { posterior segments }\end{array}$ \\
\hline P. excavatus & 5 segments & anterior 5 posterior 5 & $9.75 \pm 0.15$ & $11.55 \pm 0.31$ \\
E. eugeniae & Do & Do & $13.5 \pm 0.47$ & $18.2 \pm 0.25$ \\
E. fetida & Do & Do & $20 \pm 0.32$ & $25.6 \pm 0.21$ \\
\hline
\end{tabular}

Values are \pm SE

ganglia. Top soil endogeic worms(amphidynamic species) may have to make major changes in their physiology to enter into diapause to regain lost segments (Kale, 1993). The sub-soil earthworm species do not regenerate because their cerebral neurohormone inhibit regeneration(Chaudhuri, 1998).
New theories about the role and extents of regeneration of different parts in different species of earthworms may have to be explained at the molecular level. For example, a Homebox gene has been found to be expressed during the process of regeneration of parts of vertebrates and invertebrates (Carlson et 
al., 2001; Shenk et al., 1993; Vickery et al., 2001). In oligochaetes, engrailed - and orthodenticle- class genes have been expressed in their regeneration (Bely and Wray, 2001). Recently, Cho et al. (2009) reported up-regulation of Pex- lab 01 and Pex-lab 02 during wound healing and blastema formation process during early head regeneration in Perionyx excavatus. Differential expression of actin genes during tissue regeneration in Lumbricus terrestris was reported by Helms and Coker (2010).

Regeneration in earthworms following amputation has practical implication to the buildup of population in soil agroecosystem (Chakraborty and Chaudhuri, 2016; Jamatia and Chaudhuri, 2017) and the species possessing this property must have "comparative reproductive success" than those without this property. Further research is needed to clarify the actual mechanism of regeneration. Although the phenomenon of regeneration has attracted the attention of earthworm biologists, adequate knowledge of its mechanism is lacking.

\section{Acknowledgments}

The authors are grateful to Prof. B.K. Agarwala, Head of Zoology, Tripura University for encouragement and providing laboratory facilities and Dr. J.M. Julka and Dr. R. Paliwal, ZSI, Solan, H.P. for identification of Earthworm species. Financial assistance from the Department of Science and Technology in the form of INSPIRE research fellowship to the first author is gratefully acknowledged.

\section{References}

Balinsky, B.I.: An Introduction to Embryology. Saunders College Publishing, Philadelphia, pp. 1-768(1981).

Banik, D. and P.S. Chaudhuri: Neuroendocrine control of posterior regeneration in tropical earthworm, Eudrilus eugeniae (Kinberg). J. Life Sci., 10, 289-297 (2016).

Bely, A.E. and G.A. Wray: Evolution of regeneration and fission in annelids: Insights from ingrailed and orthodenticle gene expression. Development, 128, 2781-2791 (2001).

Bely, A.E.: Evolutionary loss of animal regeneration: pattern and process. Integr. Comp. Biol., 30, 515-527 (2010).

Biradar, P.M. and V. A. Biradar: Influence of organic wastes on the biology of epigeic earthworm, Perionyx excavatus during different seasons. J. Environ. Biol., 36, 1095-1100 (2015).

Bouche, M.B.: Relations entre less structures spatiales et fonctionelles des ecosystems, illustrees par le rele pedobiologique des vers de terre. In: La Vie dans les sols, Aspects Nouveaux, Etudes Experimentales (Ed.: P. Pesson). Gauthier Villars, pp. 187-209 (1971).

Carlson, M.R.J., Y. Komine, S.V. Bryant and D.M. Gardiner: Expression of Hox b 13 and Hox 10 in developing and regeneration of axolotl limbs and tails. Dev. Biol., 229, 296-406 (2001).

Chakraborty, S. and P.S. Chaudhuri: Earthworm communities in the bamboo plantation of west Tripura (India). Proc. Zool. Soc.(Springer). DOI: 10.1007/s12595-015-0164-5 (2016).

Chaudhuri, P.S. and S. Nath: Community structure of earthworms under rubber plantations and mixed forest in Tripura. J. Environ. Biol., 32,
537-541 (2011).

Chaudhuri, P.S., D. Chaudhuri and D.K. Nanda: Impact of posterior transection in cerebral neurosecretory elements of Indian earthworm, Eutyphoeus gammiei (Beddard). Ind. J. Physiol. Allied Sci., 52, 63-70 (1998).

Chaudhuri, P. S. , T. K. Paul, Animesh Dey, M. Datta, S. K. Dey: Effects of rubber leaf litter vermicompost on earthworm population and yield of pineapple (Ananas comosus) in West Tripura, India. Int. J. Recycl. Org. WasteAgricult., 5, 93-103 (2016).

Chaudhuri, P.S.: Kenchor Jeevan Baichitra: Kencho Projukti. Gyan Bichitra Prakashani, Kolkata, pp. 1-128 (2006).

Cho, S., Ki Seok Koh, Eun Lee and Soon Cheol Park: Differential expression of three labial genes during earthworm head regeneration. Bio. Biotec. Biochem., 73, 2609-2614 (2009).

Edwards, C.A. and P.J. Bohlen: Biology and Ecology of Earthworms. Chapman and Hall, London, 1-426 (1996).

Edwards, C.A.: Medium and high technology vermicomposting system. In: Vermiculture technology-earthworms, organic wastes and environmental management (Eds.: C.A. Edwards, N.Q. Arancon and R. Sherman). CRC Press, Taylor and Francis Group, London. pp. 91-102 (2011).

Helmes, A.J. and J.S. Cocker: Variability of actin gene expression during tissue regeneration of the earthworm Lumbricus terrestris. J. North CarolinaAcad. Sci., 20, 138-143 (2010).

Jamatia, S.K.S. and P.S. Chaudhuri: Earthworm community structure under tea plantations (Camellia sinensis) of Tripura, India. Trop. Ecol., 58, 105-113 (2017).

Kale, R.D.: Regeneration, predators and parasites of earthworms. Earthworm, Resources and Vermiculture. Director, Zoological survey of Indiapp. 101-103, (1993).

Lalthanzara, H., S.N. Ramanujan and L.K. Jha: Population dynamics of earthworms in relation to soil physico- chemical parameters in agro forestry system of Mizoram, India. J. Environ. Biol., 32, 599605 (2011).

Moment, G.B.: Growth, posterior regeneration and segment number in Eisenia foetida. Megadrilogica, 3, 167-175(1979).

Nanda, D.K. and P.S. Chaudhuri: Regeneration of the neurosecretory system of the nerve ring in Earthworm Metaphire peguna. Acta Biologica Cracoviensia, 25, 63-67 (1983).

Nanda, D.K. and P.S. Chaudhuri: The effect of cephalic transection in the ventral nerve cord- neurosecretory system of earthworm, Metaphire peguna (Rosa 1890) during anterior regeneration. Proc. IndianAcad. Sci. (Anim. Sci.), 91, 381-389 (1982).

Okrzesik, J., N. Kachamakova- Trojanowska, A. Jozkowicz, A.J. Morgan and B. Plytycz: Reversible inhibition of reproduction during regeneration of cerebral ganglia and coelomocytes in the earthworm Dendrobaena veneta. Acta Ecol. Sinica, 31, 197-204 (2013).

Shenk, M. A., L. Gee, R. E. Steele and H.R. Bode: Expression of Cnox-2, a $\mathrm{HOM} / \mathrm{HOX}$ gene was suppressed during head formation in Hydra. Dev. Biol., 160, 108-118 (1993)

Tweeten, K.A. and A. Anderson: Analysis of cell proliferation and migration during regeneration in Lumbricus variegates (Clitellata: Lumbriculidae). BIOS, 79, 183-190 (2008).

Vickery, M.C.L., M.S. Vickery, C.D. Amster and J.B. Mcclintock: Regeneration in Echinoderm larva. Micro. Res. Tech.,55, 464-473 (2001).

Xiao, N., Ge. Feng and C.A. Edwards: The regeneration capacity of an earthworm, Eisenia fetida in relation to the site of amputation along the body. Acta Ecol. Sinica., 31,197-204 (2011). 